\title{
Influence of Competence on Performance of Teachers in Public Secondary Schools in Kisii County-Kenya
}

\author{
Dr. Gilbert M. Nyakundi, PhD (Corresponding author) \\ School of Education, Mount Kenya University, Kenya \\ E-mail: gnyakundi@mku.ac.ke \\ Prof. Joseph A. Orodho, PhD \\ School of Education, Kenyatta University, Kenya \\ E-mail: Orodhojohn@gmail.com
}

\begin{abstract}
Competence is a critical aspect of employee performance; however, there is a dearth of literature on the influence of competence on teacher performance especially in public secondary schools in Kisii County. The purpose of this study was to assess influence of competence on teacher performance. Three null hypotheses were tested guided by Vroom's expectancy theory. The study adopted sequential explanatory mixed methods research design. The population constituted of 3,426 teachers from whom a sample of 345 teachers was determined using Slovene's formula. Questionnaires for teachers were used in phase one whose validity was ascertained by two experts in research while reliability as per the Cronbach Alpha method was .779. Descriptive and inferential statistics generated in phase one were analyzed according to the research objectives. In the second phase, 11 teachers were purposively selected and interviewed. Qualitative information obtained was analyzed thematically and presented by direct narration. Findings of phase one were analyzed using the Pearson's Correlation Coefficient method and yielded $\mathbf{r}(30)=-.178, \mathrm{p}>.05$ (teacher qualifications), $\mathbf{r}(30)=.200, \mathrm{p}>.05$ (professional development), and $\mathbf{r}(30)$ $=.188, \mathrm{p}>.05$ (teacher experience) respectively. The regression model constructed to measure influence of competence on performance yielded Persons' $\mathrm{R}=.335$ while adjusted R-square was $\mathrm{R}^{2}=.034$ suggesting that competence explained $3.4 \%$ of teacher performance. Consequently, qualitative findings showed that the existing performance appraisal system was mute on other teacher competence variables except for professional development. In view of these findings, the three null hypotheses were upheld leading to the conclusion that teacher competence had minimal influence on performance because of gaps in the appraisal and professional development processes. The study recommends that Teachers Service Commission should reengineer the appraisal process to focus on all teacher competence variables including qualifications, professional development and experience. Similarly, there is need to develop a professional development programme for teachers. Finally, it is recommended that further research needs to be undertaken to develop new models for performance management and professional development for teachers.
\end{abstract}

Key Words: teacher competence, development, experience, performance, qualifications

DOI: $10.7176 / \mathrm{JEP} / 11-3-19$

Publication date: January $31^{\text {st }} 2020$

\section{Introduction}

Research studies attribute teacher competence to academic ability, experience in teaching and classroom behaviour (Darling-Hammond, 2000). Teachers who join the profession possess underlying attributes that Medley (1982) as quoted by Passos (2009) referred to as 'stable traits' which are essential for successful performance. The teacher training programme enhances the academic and professional competence of teachers. According to Kulshrestha and Pandey (2013), competence is a cognitive structure that facilitates specified behaviour and is usually associated with high professional performance.

Ennis (2008) further argues that competency is the "capability of applying or using knowledge, skills, abilities, behaviours and personal characteristics to perform critical work tasks, specific functions, or operate a given role or position". Teacher 'competence' is not synonymous with 'competency' since a teacher may possess necessary competences but fail to perform effectively. The ability of teachers to effectively apply their competences in the job is an important aspect that deserves the attention of educational managers and policy-makers. Teachers demonstrate professional competency in the field, research, curriculum, emotional, social, cultural, 
communication, and lifelong learning spheres (Sahin \& Thompson, 2006; Kiymet, 2010; Zhu, Wang, Cai \& Engels, 2013).

Competency develops in a continuum and Zhu et al (2013) identify competencies such as "pedagogical skills, knowing the student, monitoring and evaluation of learning and development, school family and society relationships, knowledge of curriculum and content, teamwork, communication, problem solving and understanding the culture". Growth in teacher competency is also known as professional development. Glatthorn in Reimers (2003) argues that professional development is synonymous to "professional growth that a teacher achieves as a result of increased experience and examining his or her teaching systematically". Professional development includes both formal and informal activities such as workshops and reading professional publications respectively (Ganser, 2000).

Teacher competence is elevated by professional development either through experience or on-job training. A recent study whose findings are published in the International Journal of Education (Nyakundi, 2018) established that teacher performance ratings were not significantly related to student learning achievement scores which were consistent with an earlier study by Onderi and Croll (2009) in Gucha district. Onderi and Croll studied teacher self-perceptions of effectiveness and established that teachers considered themselves effective even when their pupils performed poorly in examinations.

The performance of a teacher depicts his or her competency. Extant literature shows that studies in teacher performance tend to associate specific teacher competence variables with student learning achievement yielding mixed results. Studies on teacher performance focus on competence variables such as qualifications, professional development and experience. For instance, teacher qualification was found to significantly influence student learning achievement by Adeyemi (2010); Darling-Hammond and Young (2002); Goe (2007); Goldhaber and Brewer (1994); Njeru and Orodho (2003) and, Yala and Wanjohi (2011) respectively. However, other studies such as Aaronson et al (2008); Buddin and Zamarro (2009); Kimani et al (2013); Koedel and Betts (2007); Kosgei, Jairo and Ayugi (2013); Rivkin et al (2005); and Zuzovsky (2005) refuted that teacher qualification significantly influence student learning achievement.

Similarly, professional development for teachers is credited for determining student learning achievement by Hill et al (2007) and Yoon, et al (2007). Additionally, teacher experience is significantly associated with student learning achievement in studies by Adeyemi (2010); Akiri (2013); Loeb and Beteille (2008); Goe (2007); Rice (2003); Rockoff et al (2008); and, Yala and Wanjohi (2011). However, Kimani et al (2013) found inconsistent results that teacher experience was not significantly related with student achievement in KCSE examinations in Nyandarua County.

Furthermore, several research studies established that teacher performance influences student learning achievement. For instance, Clotfelter et al (2007); Darling-Hammond (2007); Gordon, Kane and Staiger (2006); Kane, Kerr and Pianta (2014); Rivkin et al (2002); Rockoff et al (2008); and, Sanders and Rivers (1996) were all in agreement that teacher performance contributed significantly to student learning achievement although the contribution tended to decline beyond the first five years in teaching.

\section{Statement of the problem}

In an ideal situation, teacher performance depicts competences acquired through training, professional development and experience. However, performance appraisal ratings for teachers are high while student learning achievement is low in Kisii County. Research studies attribute student achievement factors associated with students, teachers and the school environment. Empirical studies also suggest that learning achievement could be low due to incompetence of teachers. There is a dearth of information on how teacher competences influence their performance. The contribution of competence variables such as qualifications, professional development and experience to teacher performance is unclear hence the need of this study.

\section{Objectives of the study}

The objectives if this study were to:

1. Find out the influence of qualification on teacher performance in public secondary schools in Kisii County

2. Establish influence of professional development on teacher performance

3. Determine the influence of experience on teacher performance

\section{Research Hypotheses}

This study tested the following null hypotheses: 
a) There is no significant relationship between qualification and performance of teachers in public secondary schools in Kisii County

b) Professional development does not significantly influence teacher performance

c) Teacher experience is not significantly related with teacher performance

\section{Research Design and Methodology}

The explanatory sequential mixed methods design was used in this study. The population was 3,426 teachers from whom a sample of 345 teachers was ascertained using Slovenes formula. Quantitative data was obtained in phase one from teachers using a questionnaire whose validity was determined by experts in the field and reliability established at .7 using Pearson's Correlation Coefficient Alpha. Statistical tools used to analyze data were Pearson's Correlation Coefficient Alpha, Chi-square and regression analysis. In phase two of the study, 11 teachers were interviewed to obtain data that was captured in interview forms and analyzed thematically. The second phase enhanced the completeness of findings of the first phase of the study.

\section{Findings and Discussions}

This section presents research findings from both the first and second phase of this study.

\section{A. Phase one: Quantitative findings}

The results on relationships among teacher competency variables using Pearson Correlation Coefficient method shows that academic qualification and professional development yielded a coefficient $\boldsymbol{r}(341)=0.106, \boldsymbol{p}$-value $=$ $0.03<0.05$ which depict a weak positive relationship but significant at $5 \%$ level of confidence. However, the relationship between professional development and experience had a coefficient $\quad \boldsymbol{r}(341)=-0.327, \boldsymbol{p}$ value $=0.000<0.05$ depicting a negative relationship but statistically significant at $5 \%$ level of confidence. Similarly, academic qualification and experience had a coefficient $\boldsymbol{r}(341)=-0.141$, $\boldsymbol{p}$-value $=0.006<0.05$ indicating a weak and negative relationship but statistically significant at $5 \%$ level of confidence as shown in Table 1 .

Table 1:

Relationship between competence and teacher performance

\begin{tabular}{clcccc}
\hline & Variables & Performance & Qualification & Development & Experience \\
\hline \multirow{4}{*}{$\begin{array}{c}\text { Pearson Correlation } \\
(\boldsymbol{r})\end{array}$} & Performance & 1 & -0.022 & -0.068 & 0.332 \\
& Qualification & -0.022 & 1 & 0.106 & -0.141 \\
& Development & -0.068 & 0.106 & 1 & -0.327 \\
& Experience & 0.332 & -0.141 & -0.327 & 1 \\
\hline \multirow{3}{*}{$\boldsymbol{p}$-value } & Performance & - & 0.447 & 0.342 & 0.018 \\
& Qualification & 0.447 & - & 0.03 & $0.006^{*}$ \\
& Development & 0.342 & $0.03 *$ & - & 0.000 \\
& Experience & $0.018^{*}$ & 0.006 & $0.000^{*}$ & - \\
\hline
\end{tabular}

$\mathbf{N}=341, \boldsymbol{\alpha}=0.05 *$ Significant at 0.05 level of confidence

Source: Filed data

The first research objective was to determine influence of teacher qualification on teacher performance. Table 1 shows the results of the Pearson's correlation coefficient as $\boldsymbol{r}(341)=-0.022, \boldsymbol{p}$-value $=0.447>0.05$ for academic qualification and teacher performance which indicate a weak negative relationship that is not statistically significant at $5 \%$ level of confidence.

The second research question was to establish influence of professional development on teacher performance. Results of the Pearson's correlation coefficient method yielded $\boldsymbol{r}(341)=-0.068, \boldsymbol{p}$-value $=0.342>0.05$ depicting that professional development and teacher performance had a weak and negative relationship that was not significantly at $5 \%$ level of confidence.

The third research objective was to find out influence of experience on teacher performance and results yielded a coefficient $\boldsymbol{r}(341)=0.332, \boldsymbol{p}$-value $=0.018<0.05$ which indicates a weak positive relationship but statistically significant at $5 \%$ level of confidence. 
These results show that teacher experience is related significantly with teacher performance at $5 \%$ level of confidence. The results also depict that although qualifications and professional development are not significantly related to teacher performance, there was a significant linear relationship between the three variables respectively. Table 2 shows Chi-square statistics that were generated to explain further the relationships between teacher competence and performance.

Table 2

\begin{tabular}{lccc} 
Chi-Square statistics for teacher competence and teacher performance \\
\hline Determinants & Pearson Chi-Square & df & p-value \\
Qualifications & 13.752 & 12 & 0.317 \\
Professional Development & 1.004 & 2 & 0.605 \\
Experience & 5.930 & 4 & 0.204 \\
\hline
\end{tabular}

$N=341, \alpha=0.05 *$ Significant at 0.05 level of confidence

Source: Field data

Table 2 shows $\chi^{2}(12, \mathrm{~N}=341)=13.752, \mathrm{p}=0.317>0.05$ for qualifications; a $\chi^{2}(2, \mathrm{~N}=341)=1.004, \mathrm{p}=0.605>0.05$ for professional development and a $\chi^{2}(4, \mathrm{~N}=341)=5.930, \mathrm{p}=0.204>0.05$ for teacher experience. These results show that the three variables of teacher competence had weak positive relationships with teacher performance though not significant at $5 \%$ level of confidence. Consequently, results from a regression model developed to test the three null hypotheses of this study are presented in Table 3.

Table 3

Regression statistics of teacher competence and performance

\begin{tabular}{|c|c|c|c|c|c|c|c|}
\hline Model & $\mathbf{R}$ & R Square & \multicolumn{2}{|c|}{ Adjusted R Square } & \multicolumn{3}{|c|}{ Std. Error of the Estimate } \\
\hline 1 & $0.335^{\mathrm{a}}$ & 0.113 & \multicolumn{2}{|c|}{0.034} & \multicolumn{3}{|c|}{0.802} \\
\hline \multicolumn{8}{|c|}{ Predictors: (Constant), Experience, Qualifications and Professional Development } \\
\hline \multicolumn{8}{|c|}{ Dependent Variable: Teacher Performance } \\
\hline \multicolumn{8}{|c|}{ Coefficients } \\
\hline \multicolumn{3}{|c|}{ Variables } & B & Std. Error & Beta & $\mathbf{t}$ & Sig. \\
\hline \multicolumn{3}{|c|}{ (Constant) } & 2.839 & 0.819 & & 3.468 & 0.001 \\
\hline \multicolumn{3}{|c|}{ Qualifications } & 0.012 & 0.087 & 0.022 & 0.136 & 0.893 \\
\hline \multicolumn{3}{|c|}{ Professional Development } & 0.098 & 0.385 & 0.044 & 0.254 & 0.801 \\
\hline \multicolumn{3}{|c|}{ Experience } & 0.583 & 0.287 & 0.349 & 2.03 & 0.05 \\
\hline
\end{tabular}

Source: Field data

The regression model produced $\mathrm{R}^{2}$ value of 0.113 which was adjusted to 0.034 and a Standard Error of 0.802 which depicts that teacher competence is a weak predictor of teacher performance. The coefficient of academic qualification .012 was not significantly different from zero because its $\boldsymbol{p}$-value 0.893 was greater than 0.05 level of significance. The results imply that for every unit increase in academic qualification, a 0.012 unit increase in teacher performance was predicted holding all other factors constant.

Similarly, the coefficient of professional development 0.098 was not significantly different from zero because its $\boldsymbol{p}$-value of 0.801 was greater than 0.05 level of confidence. The results imply that for every unit increase in professional development, a 0.098 unit increase in teacher performance was predicted holding all other factors constant.

Furthermore, the coefficient of teacher experience was .583 that is significantly different from zero because its $\boldsymbol{p}$ value was equal to 0.05 level of confidence. The result depicts that for every unit increase in teacher experience; a 0.583 increase in teacher performance was predicted holding all other factors constant.

\section{B. Qualitative findings}

In the second phase of this study, eleven teachers were purposively selected for interviewing based on their competences and performance. Two teachers were selected from each of the six levels of qualification ranging 
from Diploma in Teacher Education (DTE) to Doctor of Philosophy (Ph.D.). The two teachers in each qualification level represented the most and least experienced who also recorded the highest and lowest performance respectively.

The teachers were asked four questions and data obtained using interview schedules, analyzed thematically and presented according to the three research objectives. The first research objective sought to determine influence of qualifications on teacher performance. Teachers were asked whether their level of academic and professional qualifications influenced their performance. Interviewees agreed that teacher qualifications did not determine their performance. For instance, one teacher stated that:

We are trained to teach effectively but many times we encounter challenges in our schools. Our certificates do not matter when it comes to teaching. In fact, students taught by some of us with higher degrees do not perform any better than those taught by teachers with diploma certificates. Even our performance does not differ significantly from that of newly employed teachers. Infact, some newly employed teachers perform better than some experienced teachers. (T4)

Furthermore, one newly employed teacher responded that:

As a newly teacher I have to work much harder to come up with the level of performance achieved by experienced teachers. Qualifications are of little impact since teaching is practical and depends on the environment, the nature of students and even the school management. Some principals can make it difficult for teachers to perform optimally by despising them in order to settle personal differences. (T1)

Teachers agreed that qualifications did not have a lot of influence on their performance. The second question was to find out whether teachers felt that their development helped them to perform their work better. One teacher stated that:

We attend various seminars and workshops in order to boost our chances for promotion. Development opportunities are scarce so any available opportunity is attractive to teachers. Sometimes, principals select some teachers and leave out others and this is so demotivating. (T7)

The statements from teachers show that teachers were aware that available development opportunities are insufficient and inappropriate. These findings points to the policy on professional development of teachers. The third interview question was intended to gather the views of teachers on how experience impacted on their performance. One of the teachers remarked that:

It does not matter how long a teacher has been teaching. Performance depends on how well motivated the teacher is. If the teacher is well remunerated and supported by the school administration, he/she can perform optimally and vice versa. In most cases the two situations are lacking. (T11)

Qualitative findings collaborated with quantitative findings. The fact that teacher qualifications and development were not significantly related with teacher experience shows that teachers could've withheld their performance for being demotivated as reported during interviews in the second phase on the study. The findings of phase two helped to explain further quantitative findings obtained in phase one.

\section{Discussions of Research Findings}

Although the relationships between the three teacher competence variables were weak, they were all significant. Prior research shows that academic qualification, professional development, and teacher for teacher experience are related (Passos, 2009; Pianta \& Hamre, 2009). The results of this study are consistent with previous research findings.

Previous research also depicts significant relationships between teacher competence and teacher performance. For instance, Kulshrestha and Pandey (2013) suggest that teacher competence is associated with high professional performance. Similarly, Ennis (2008) argues that individual teacher competencies significantly predict performance and success. But the results of this study were mixed on this respect because academic qualifications for instance, were negatively related with teacher performance and the relationship was not significant. This finding is not unique because in complex environments mastery of relevant knowledge and skills alone cannot guarantee successful performance (Westera, 2001, in Passos, 2009). However, Westera (2001) agrees that "competent performance presumes competence". This argument suggests that though academic qualifications are important, they are not synonymous with teacher competence.

The findings of this study also show that experience and teacher performance are positively related. Although the relationship is weak relationship, it is statistically significant thus giving credence to the need for performance appraisal policy for teachers. However, professional development and teacher performance were negatively related 
and the relationship is insignificant pointing to literature review which shows lack of a policy on professional development for teachers (Republic of Kenya 2014).

Although in-service training (INSET) programmes are construed as professional development programmes, they are plagued with a myriad of problems. The INSET programme face threats which include "shortage of teacher educators, shallow content coverage and delivery, de-contextualization, unmet aspirations, insufficient inclusivity, limited diversity of resources, and inadequate funding" (Gathumbi, Njoroge \& Denna, 2013). As a result, there is need for a comprehensive policy to address these challenges and transform in-service training programs into highly professional development programs (Gathumbi et al, 2013). Thus the finding that experience is significantly related with performance points to the need to formulate appropriate policy on professional development for teachers in Kenya.

\section{Conclusions and Recommendations}

The findings of this study led to three conclusions notably: (1) Linear relationships between teacher qualifications, professional development and experience suggests that performance appraisal for teachers should consider the three teacher competence variables, (2) though teacher qualification and development were not directly related with teacher performance, they are importance aspects of competence, (3) teacher performance is a function of teacher qualifications, professional development and experience.

Consequently, the following three policy recommendations were suggested:

a) Teachers Service Commission should re-engineer the appraisal process to focus on all teacher competence variables including qualifications, professional development and experience.

b) Teachers Service Commission should spearhead policy development on professional development for teachers.

c) The Kenya Education Staff Institute (KESI) and Kenya Education Management Institute (KEMI) should spearhead development of curricula for teacher professional development programme.

d) There is need for further research to develop new models of performance management and professional development for teachers.

\section{Acknowledgements}

This study was successful courtesy of the support and participation of the Commissioner and Director of Education in Kisii County, principals, deputy principals, heads of departments and teachers. Sincere gratitude is extended to all persons who in some way contributed to the completion of this study.

\section{References}

Abadzi, H. (2007). Absenteeism and beyond: instructional time loss and consequences. The World Bank Independent Evaluation Group. Policy Research Working Paper 4376.www.worldbank.org/. Accessed on $30 / 08 / 20016$

Adeyemi, T.O. (2010). Teachers' teaching experience and students' learning outcomes in secondary schools in Ondo State, Nigeria. Educational Research and Review. 3(6): 204-212.

Akiri, A. (2013). Effect of teachers' effectiveness on students' academic performance in public secondary schools, Delta state, Nigeria. Journal of Educational and social Research. 3(3): 105- 112

Buddin, R. \& Gema, Z. (2009). Teacher qualifications and student achievement in urban elementary schools. Santa Monica, CA: RAND Corporation. https://www.rand.org/pubs/reprints

Boxall, P.F. \& Purcell, J. (2003) Strategy and human resource management. Basingstoke: Palgrave Macmillan.

Clotfelter, C.T., Ladd, H.F. \& Vigdor, J.L. (2007). How and why do teacher credentials matter for student achievement? National Bureau of Economic Research, Working Paper 2828. Cambridge, MA: National Bureau of Economic Research 
Darling-Hammond, L. (2000). Teacher Quality and Student Achievement: A review of state policy evidence. Seattle, WA: Center for the Study of Teaching and Policy, University of Washington.

Darling-Hammond, L. \& Youngs, P. (2002). Defining highly qualified teachers: What does scientifically-based research tell us? Educational Researcher, 31 (9), 1325

Ennis, M. (2008). Competency models: A Review of the Literature and the role of the employment and training administration (ETA). U.S. Department of Labour

Ganser, T. (2000). An ambitious vision of professional development for teachers. National Association of Secondary School Principals, 84(618), 1-7.

Gathumbi, Njoroge \& Hintze (2013) Towards Comprehensive Professional Development of Teachers: The Case of Kenya, International Journal of Process Education, 5 (1).

Glatthorn, A. (1995). Teacher development. In: Anderson, L. (Ed.), International teaching and teacher education (second edition). London: Pergamon Press.

encyclopedia of

Goe, L. (2007). The link between teacher quality and student outcomes: A research synthesis. Washington, DC: National Comprehensive Center for Teacher Quality/Retrieved from http://www.tqsquare.org/link.php

Goldhaber, D. D., \& D. J. Brewer (1997). "Why Don’t Schools and Teachers Seem to Matter? Assessing the Impact of Un-observables on Educational Productivity". Journal of Human Resources. 32(3).

Gordon, R., Kane, T.J, \& Staiger, D.O. (2006). Identifying effective teachers using performance on the job. Washington, DC: The Brookings Institution.

Hill, H.C., Ball, D.L., Blunk, M., Goffney, I.M., \& Rowan, B. (2007). Validating the ecological assumption: The relationship of measurement scores to classroom teaching and student learning. Measurement: Inter disciplinary Research and Perspective, 5,107-118. doi: 101080/1536630701487138

Kimani, N. G, Kara, M.A. \& Njagi, W.L. (2013). Teacher factors influencing students' academic achievement in secondary schools in Nyandarua County, Kenya. International Journal of Education and Research.1 (3)114. Maputo. ADEA.

Kiymet, S. (2010). Teacher competencies. Cultura, international journal of philosophy of culture and Axiology. 7 (1)

Koedel, C., Betts, J. (2007). Re-Examining the role of teacher quality in the educational production function, working paper, University of California, San Diego.

Kosgei, A. M., Jairo K. O. O., \& Ayugi, M.E (2013). Influence of teacher characteristics on students' academic achievement among secondary schools. Journal of Education and Practice, 4 (3). pp. 76-82. ISSN 22221735

Kulshrestha, A.K. \& Pandey, K. (2013). Teachers training and professional competencies. Vice of Research. 1 (4)

Loeb, S., \& Beteille, T. (2008). Teacher labor markets and teacher labor market research. In G. Duncan \& J. Spillane (Eds.), Teacher quality: Broadening and deepening the debate (pp. 27-58). Evanston, IL: Northwestern University.

Medley, D.M. (1982). Teacher Effectiveness. In Mitzel, H.E. (ed.) Encyclopedia of Educational Research, 5th Edition. New York, NY: The Free Press.

Njeru, E.H.N \& Orodho, J.A (2003). Access and Participation in Kenya. Nairobi. Institute of Policy Analysis and Research.

Nyakundi, M.G. (2018). Influence of teacher performance on student learning achievement in public secondary schools in Kisii County-Kenya. International Journal of Education. 2(10)

Passos, A.F.J. (2009). A comparative analysis of teacher competence and its effect on pupil performance in upper primary schools in Mozambique and other SACMEQ Countries. Thesis, University of Pretoria, South Africa

Republic of Kenya (2014). National Education Sector Plan (NESP), Nairobi: Ministry of Education, Science and Technology

Rice, J. K. (2003). Teacher quality: Understanding the effectiveness of teacher attributes. Washington, $\quad$ DC: Economic Policy Institute. 
Rivkin, S., Hanushek, E., \& Kain, J. (2005). Teachers, schools, and academic achievement. Econometrica, 73(2), 417-458.

Rockoff, J.E., Jacob, B.A., Kane, T.J., \& Staiger, D.O. (2008). Can you recognize an effective teacher when you recruit one? (NBER Working Paper No.14485). Cambridge, MA: National Bureau of Economic Research. Retrieved from htttp://www.nber.org/papers/w14485

Sahin, I. \& Thompson, A. (2006) 'Using Rogers theory to interpret instructional computer use by COE faculty', Journal of Research on Technology in Education, vol. 39, no.1, pp. 81-104.

Sanders, W. \& Rivers, J. (1996). "Cumulative and residual effects of teachers onfuture student academic achievement." University of Tennessee Value Added Research and Assessment Center.

Yala, P.O., \& Wanjohi, W.C. (2011). Performance determinants of KCSE in Mathematics in secondary schools in Nyamira Division-Kenya. Asian Journal of Social Science, 7 (20): 107-112.

Yoon, K. S., Duncan, T., Lee, S. W., Scarloss, B., \& Shapley, K. L. (2007). Reviewing the evidence on how teacher professional development affects student achievement. Washington, DC: Regional Educational Laboratory Southwest. Retrieved from http://ies.ed.gov/ncee/edlabs

Zhu C., Wang, D., Cai., Y. H. \& Engels, N. (2013). What core competencies are related to teachers' innovative teaching? Asia-Pacific Journal of Teacher Education, 41 (1)9-27. Accessed from, http://dx.doi.org/10.1080/1359866X.2012.753984

Zuzovsky, R. (2005). Teachers' qualifications and their impact on student achievement: Findings from TImss 2003 data for Israel. Center for Science and Technology Education, Tel Aviv University, Tel Aviv, Israel. Pdf. Accessed online 30/07/2017 